\title{
ADVANCES IN STATIONARY AND PORTABLE FUEL CELL APPLICATIONS
}

\begin{abstract}
The reliance on fossil fuels is one of the most challenging problems that need to be dealt with vigorously in recent times. This is because using them is not sustainable and leads to serious environmental issues, such as: air pollution and global warming. This condition affects economic security and development. An alternative to fossil fuel is highly possible which will be more environmentally friendly, sustainable and efficient as well. Among all the different technologies associated with renewable energy, fuel cell technologies represent one of the most promising technological advancement to curb the situation.

In this paper, an overview of the technology and its advantages and disadvantages compared with competitive technologies was revealed. The application of different fuel cell types in the stationary and portable sectors was covered. Furthermore, recent challenges and promising developments of current fuel cell technologies in different studied applications were reviewed. Some possible solutions to the challenges were named in this paper for both the portable and stationary fuel cell applications. The paper further seeks to expose the world to the current progress made in the fuel cell industry up to date and possible areas that needs intensified research and modifications to make the fuel cell industry more vibrant and buoyant.
\end{abstract}

Keywords: Fuel cell, stationary, portable, hydrogen, energy storage, renewable energy.

\section{INTRODUCTION}

One of the biggest challenges the world is facing is to find suitable, sustainable and clean replacements for fossil fuels. Fossil fuels are ultimately unsustainable, and depending on them as main power source leads to serious environmental issues such as pollution and climate change, along with economic and political issues related to the economy, security, and the political problems affecting the exporting countries. On the other hand, the use of renewable energy is already growing. Of the 300 gigawatts of new electricity generation capacity built globally between 2008 and 2009, about 140GW was the capacity generated from renewable sources. In 2005, renewables produced $16.5 \%$ of world primary energy. According to the special report on renewable energy sources and climate change mitigation (SRREN) [1,2], renewable energy could 
account for almost $80 \%$ of the world's energy supply within four decades. Fuel cells technology is one of the most promising technologies that can be developed in relation with the increasing renewable energy supply.

Fuel cell according to [3] is gradually becoming a practical technology option that competes with conventional internal combustion engine generators and batteries. In 2012, shipment of fuel cell systems increased appreciably almost double that of the previous year to reach a total of 45,700 units. This figure in 2013 was also anticipated to increase by a margin of $46 \%$ approaching about 67,000 units. Stationary fuel cells experienced the largest growth compared to the three main sectors. The standout performer for fuel cell technology is currently the stationary sector. Its application is normally found in different sizes; from small - scaled grid connected micro combined power heat and power units for residential use, to off - grid backup power systems providing uninterrupted power supplies to critical infrastructure, and prime power for buildings and even to megawatt - scale installations designed as grid - connected power stations.

Based on events in 2014, it is again anticipated that 2015 will be one of the years of massive progress and development in the fuel cell industry. This will surely be highly experienced in the three $[4,5]$ main regions for hydrogen fuel cells (HFC) markets, that is, Europe, Asia and North America. In 2014, California remained number one in the United States in the commercialization of HFC. This transformation was also seen in Japan with 41 hydrogen fueling stations (HFS) being implemented due to the enforcement of positive measure and massive support for HFC. Korea within the same year built the Gyeonggi Green Energy, 59MW as well. This is currently the world's largest fuel cell park for the stationary market. By July 2014, Korea announced the commencement of the Pyeongtaek, 360MW which is anticipated to be completed by 2018.

The fuel cells annual report 2014 also stipulated how the portable sector was going through some difficulties to support the financial and commercial viability of the HFC market but the release of the Upp ${ }^{\mathrm{Tm}}$, a USB compatible charging device by the Intelligent Energy (IE) changed the general perception and future of the portable sector. The transport industry also saw massive progress as more fuel cell electric vehicles (FCEV) were manufactured. Hyundai for instance introduced the I×35 FCEV, while Toyota during that period also generated the Mirai 2015. 


\section{FUEL CELL OVERVIEW}

A fuel cell is an electro-chemical power source which converts chemical energy in the form of fuel directly into electrical energy [6]. Fuel cells technology allows the direct conversion of chemical energy to electrical energy, instead of the multi-step processes involved in combustion-based heat engines $[7,8]$. However, unlike other electro-chemical power sources such as batteries which store their reactants within a cell, the reactants are fed continuously to the fuel cell from external stores. Also, the electrodes in a fuel cell are not consumed as in a battery, irreversibly in a primary cell and reversibly in a secondary cell, and do not take part in the reaction. Fuel cells are identified as one of the most promising technologies that are significantly related to the renewable energy development $[6,9]$.

Although the concept of a fuel cell was developed in England in the 1800s by Sir William Grove, the first workable fuels cells were not produced until much later, in the 1950s. During this time, interest in fuel cells increased, as NASA began searching for ways to generate power for space flights [10]. Fuel cells technology is nowadays considered as one of the most promising technologies that are needed to develop in according with the increasing renewable energy supply. Employing fuel cells eliminates pollution caused by burning fossil fuels, as the only by-product is water, and they don't need conventional fuels such as oil or gas and can therefore eliminate economic dependence on politically unstable countries. Alternatively, hydrogen and other fuel cell fuels can be produced anywhere and on different scalable volume, which leads to more stabilized and decentralized power grid on the long term. Fuel cell systems perform with the highest efficiency compared to conventional distributed energy systems, and they are able to produce nearzero greenhouse emissions if working with renewable clean resources [11- 14].

Compared with combustion engines, fuel cells have no moving parts (except for pumps or compressors in some fuel cell plant subsystems), which allows silent, vibration-free and noise-less operations, with less maintenance required. Fuel cell operating temperatures vary from around $80^{\circ} \mathrm{C}$ for low-temperature PEMFCs to around $1000^{\circ} \mathrm{C}$ for MCFCs. Temperatures inside combustion engines may reach over $2000^{\circ} \mathrm{C}$. Compared with batteries, fuel cells nearly provide instantaneous recharge capability $[6,101]$. They can use a variety of different fuels to generate power (e.g. hydrogen, methanol, fossil fuels to biomass-derived materials, etc.). Fuel cells in general can offer longer operating times, operating on much wider range of temperature, and 
having less environmental issues associated with disposal. Advantages of fuel cells over each of combustion engines and batteries are summarized in Table 1.

Table 1: Advantages of fuel cells compared to each of combustion engines and batteries.

\begin{tabular}{|l|l|}
\hline Compared to combustion engines & Compared to batteries \\
\hline Higher efficiency & Longer operating times \\
\hline Less pollution and greenhouse gases & Wider temperature range \\
\hline Silent and smooth operating & $\begin{array}{l}\text { Reduced environmental issues associated with } \\
\text { disposal. }\end{array}$ \\
\hline Less maintenance & Can work on different fuels \\
\hline More economic secure & instantaneous recharge capability \\
\hline Can work on variety of fuels & \\
\hline
\end{tabular}

Fuel cells are already commercially used to generate electricity for some applications, including in spacecraft and in few stationary uses, such as emergency power generators. Today, fuel cells have reached a level of development from which it is possible to indicate that they have promising markets in which electricity must be produced with high efficiency and low environmental impact [11]. Moreover, numerous fuel cell-based power plants have been built and operated successfully, on different scalable designs from tens of megawatt to a few milliwatts [12]. However, fuel cell cost is one barrier that is facing the commercialization of fuel cell technology in different applications. Fuelling fuel cells is another fundamental problem since the production, transportation, distribution and storage of reactant is still technically challenging. Other limitations include the durability and reliability of the fuel cell system. In this paper, an overview of the fuel cell technology and its different types is given. Application of different types of fuel cells is covered in the stationary and portable power sectors. Furthermore, this paper highlighted the main challenges associated with using different fuel cell types in the studied applications. Recent developments that deal with the proposed challenges were reported. 


\section{FUEL CELL POPULAR TYPES}

The basic physical structure of a fuel cell consists of an electrolyte layer in contact with two porous electrodes, both electrodes contain catalysts to speed up the electrochemical processes; one electrode is negatively charged (anode) and the other electrode is positively charged (cathode), as it is shown in Fig.1. Electrochemical reactions take place at the electrodes to produce an electric current. The basic operation of the hydrogen fuel cell is the reverse situation of the process of the electrolysis; the hydrogen and oxygen are recombining, and an electric current is produced along with the water obtained [13]. The overall reaction is described in the following equation:

$$
\mathrm{H}_{2}(\mathrm{~g})+1 / 2 \mathrm{O}_{2}(\mathrm{~g}) \rightarrow \mathrm{H}_{2} \mathrm{O}+\text { energy }
$$

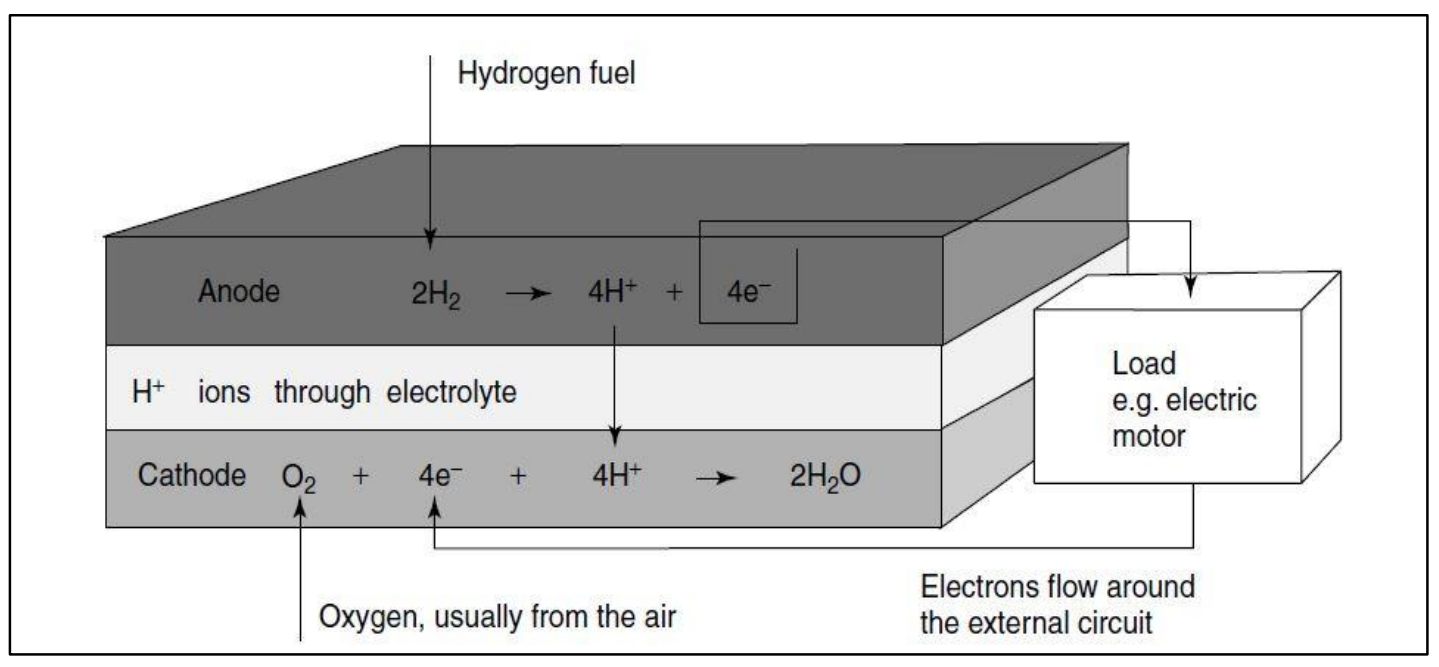

Fig 1: Acid electrolyte fuel cell scheme [10]

We can distinguish two main categories of fuel cells, depending on the kind of electrolyte which is used: acid electrolyte fuel cells and alkaline electrolyte fuel cells. In both types, the overall reaction is the same as displayed in Eq. 1, but the half reactions at each electrode are different. The main difference between them is the charge carrier: a positive one for the first type, and a negative one for the second type. At the anode of the acid electrolyte fuel cell, the hydrogen gas ionises, releasing electrons and $\mathrm{H}^{+}$ions (protons), while at the cathode, oxygen reacts with electrons arriving through the circuit, and $\mathrm{H}^{+}$ions that are passing through the electrolyte, to form water. On the other hand, in the alkaline electrolyte fuel cell, hydroxyl ions $\left(\mathrm{OH}^{-}\right)$are made at the cathode, and then at the anode they react with hydrogen, releasing electricity and producing water. At the cathode, oxygen reacts with electrons producing new $\left(\mathrm{OH}^{-}\right)$ions. Similar to the acid fuel cells, 
alkaline electrolyte fuel cells, to allow to these reactions to proceed continuously, the ions must be able to pass through the electrolyte, while electrons pass from the anode to the cathode through the electric circuit [13]. In the Table 2 different half-reactions for both alkaline and acid fuel cells are presented.

TABLE 2. HALF REACTIONS OF ACID AND BASIC ELECTROLYTE FUEL CELLS.

\begin{tabular}{|l|l|l|}
\hline & Acid electrolyte & Basic electrolyte \\
\hline Anode reaction & $\mathrm{H}_{2} \rightarrow 2 \mathrm{H}^{+}+2 \mathrm{e}^{-}$ & $\mathrm{H}_{2}+2 \mathrm{OH}^{-} \rightarrow 2 \mathrm{H}_{2} \mathrm{O}+2 \mathrm{e}^{-}$ \\
\hline Cathode reaction & $1 / 2 \mathrm{O}_{2}+2 \mathrm{H}^{+}+2 \mathrm{e}^{-} \rightarrow \mathrm{H}_{2} \mathrm{O}$ & $1 / 2 \mathrm{O}_{2}+\mathrm{H}_{2} \mathrm{O}+2 \mathrm{e}^{-} \rightarrow 2 \mathrm{OH}^{-}$ \\
\hline Overall reaction & $\mathrm{H}_{2}+1 / 2 \mathrm{O}_{2} \rightarrow \mathrm{H}_{2} \mathrm{O}$ & $\mathrm{H}_{2}+1 / 2 \mathrm{O}_{2} \rightarrow \mathrm{H}_{2} \mathrm{O}$ \\
\hline
\end{tabular}

Fuel cells can also be categorized into different types based on the reactant type used (hydrogen, methanol, methane, carbon monoxide and other organic substances, etc.); the electrolyte type (acid or alkali, liquid or solid), and the operating temperature (low-temperature fuel cells $-120^{\circ} \mathrm{C} / 150^{\circ} \mathrm{C}$, intermediate temperature fuel cells $-150^{\circ} \mathrm{C} / 250^{\circ} \mathrm{C}$, interim-temperature fuel cells $-250^{\circ} \mathrm{C} / 650^{\circ} \mathrm{C}$, high-temperature fuel cells - over $650^{\circ} \mathrm{C}$ ) [12]. An overview of the main 14 different types of fuel cells has been made, and the main features are shown in Table 3 and Table 4.

TABLE 3. MAIN FEATURES OF DIFFERENT TYPES OF FUEL CELLS: FUEL, CATALYST AND ELECTROLYTE.

\begin{tabular}{|l|l|l|l|}
\hline & Fuel & Catalyst & Electrolyte \\
\hline $\begin{array}{l}\text { Low-Temperature } \\
\text { Proton Exchange } \\
\begin{array}{l}\text { Membrane Fuel } \\
\text { Cells (LT-PEMFCs) }\end{array}\end{array}$ & \multirow{2}{*}{ Hydrogen $\left(\mathrm{H}_{2}\right)$} & Platinum supported on carbon & $\begin{array}{l}\text { Solid polymer membrane } \\
\text { (Nafion) }\end{array}$ \\
\cline { 1 - 4 } $\begin{array}{l}\text { High-Temperature } \\
\text { Proton Exchange } \\
\text { Membrane Fuel } \\
\text { Cells (HT-PEMFCs) }\end{array}$ & & Platinum-Ruthenium supported & Nafion/PBI doped in phosphoric \\
acid carbon & \\
\hline $\begin{array}{l}\text { Phosphoric Acid } \\
\text { Fuel Cells (PAFCs) }\end{array}$ & Hydrogen $\left(\mathrm{H}_{2}\right)$ & Platinum supported on carbon & $\begin{array}{l}\text { Liquid phosphoric acid (H3PO4) } \\
\text { in silicon carbide (SiC) }\end{array}$ \\
\hline
\end{tabular}




\begin{tabular}{|c|c|c|c|}
\hline $\begin{array}{l}\text { Direct Methanol } \\
\text { Fuel Cells (DMFCs) }\end{array}$ & $\begin{array}{l}\text { Liquid } \\
\text { methanol-water } \\
\text { solution }\end{array}$ & $\begin{array}{l}\text { Platinum/Platinum-Ruthenium } \\
\text { supported on carbon }\end{array}$ & $\begin{array}{l}\text { Solid polymer membrane } \\
\text { (Nafion) }\end{array}$ \\
\hline $\begin{array}{l}\text { Direct Ethanol Fuel } \\
\text { Cells (DEFCs) }\end{array}$ & $\begin{array}{l}\text { Liquid ethanol- } \\
\text { water solution }\end{array}$ & $\begin{array}{l}\text { Platinum/Platinum-Ruthenium } \\
\text { supported on carbon }\end{array}$ & $\begin{array}{l}\text { Solid } \quad \text { Nafion/Alkaline } \\
\text { media/Alkaline-acid media }\end{array}$ \\
\hline $\begin{array}{l}\text { Alkaline Fuel Cells } \\
\text { (AFCs) }\end{array}$ & Hydrogen (H2) & Nickel/Silver supported on carbon & $\begin{array}{l}\text { Potassium hydroxide (KOH) in } \\
\text { water solution/Anion exchange } \\
\text { membrane (AEM) }\end{array}$ \\
\hline $\begin{array}{l}\text { Molten Carbonate } \\
\text { Fuel Cells (MCFCs) }\end{array}$ & Methane & $\begin{array}{l}\text { Nickel Chromium (NiCr)/Lithiated } \\
\text { nickel (NiO) }\end{array}$ & $\begin{array}{l}\text { Liquid alkali carbonate } \\
\left(\mathrm{Li2} \mathrm{Co}_{3} / \mathrm{Na}_{2} \mathrm{CO}_{3} / \mathrm{K}_{2} \mathrm{CO} 3\right) \\
\text { Lithium aluminate }(\mathrm{LiAlO} 2)\end{array}$ \\
\hline $\begin{array}{l}\text { Solid Oxide Fuel } \\
\text { Cells (SOFCs) }\end{array}$ & Methane & $\begin{array}{l}\text { Nickel-YSZ composite/Strontium- } \\
\text { doped lanthanum manganite } \\
\text { (LSM) }\end{array}$ & $\begin{array}{l}\text { Solid yttria-stabilized zirconia } \\
\text { (YSZ) }\end{array}$ \\
\hline $\begin{array}{l}\text { Proton Ceramic } \\
\text { Fuel Cells (PCFCs) }\end{array}$ & Methane & Nickel & Protonic/Zirconia \\
\hline $\begin{array}{l}\text { Zinc-Air Fuel Cells } \\
\text { (ZAFCs) }\end{array}$ & Zinc & $\begin{array}{l}\text { Non-noble metal oxides (such as } \\
\text { manganese oxide- } \mathrm{MnO} 2 \text { ) }\end{array}$ & Liquid alkalines \\
\hline $\begin{array}{l}\text { Direct Borohydride } \\
\text { Fuel Cells (DBFCs) }\end{array}$ & $\begin{array}{l}\text { Sodium } \\
\text { borohydride } \\
\left(\mathrm{NaBH}_{4}\right)\end{array}$ & $\begin{array}{l}\text { Gold/Silver/Nickel/Platinum } \\
\text { supported on carbon }\end{array}$ & $\begin{array}{l}\text { Solid Nafion/Anion exchange } \\
\text { membrane (AEM) }\end{array}$ \\
\hline $\begin{array}{l}\text { Direct Formic Acid } \\
\text { Fuel Cells } \\
\text { (DFAFCs) }\end{array}$ & $\begin{array}{l}\text { Liquid formic } \\
\text { acid }(\mathrm{HCOOH})\end{array}$ & $\begin{array}{l}\text { Palladium/Platinum supported on } \\
\text { carbon }\end{array}$ & Solid Nafion \\
\hline $\begin{array}{l}\text { Direct Carbon Fuel } \\
\text { Cells (DCFCs) }\end{array}$ & 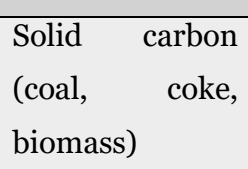 & $\begin{array}{l}\text { Graphite or carbon-based } \\
\text { material/Strontium-doped } \\
\text { lanthanum manganite (LSM) }\end{array}$ & $\begin{array}{l}\text { Solid yttria-stabilzed zirconia } \\
\text { (YSZ)/Molten carbonate/Molten } \\
\text { hydroxide }\end{array}$ \\
\hline $\begin{array}{l}\text { Enzymatic } \quad \text { Fuel } \\
\text { Cells (BFCs) }\end{array}$ & $\begin{array}{l}\text { Organic matters } \\
\text { (glucose) }\end{array}$ & Biocatalyst supported on carbon & $\begin{array}{l}\text { Ion exchange } \\
\text { Membrane/Membrane-less }\end{array}$ \\
\hline $\begin{array}{ll}\text { Microbial } & \text { Fuel } \\
\text { Cells (BFCs) } & \end{array}$ & $\begin{array}{l}\text { Any organic } \\
\text { matter (glucose, }\end{array}$ & $\begin{array}{lcc}\text { Biocatalyst supported } & \text { on } \\
\text { carbon/Platinum } & \text { supported } & \text { on } \\
\text { carbon } & & \end{array}$ & Ion exchange Membrane \\
\hline
\end{tabular}




acetate, waste-
water)

TABLE 4. MAIN FEATURES OF DIFFERENT TYPES OF FUEL CELLS: ELECTRICAL EFFICIENCY, OPERATING TEMPERATURE AND CHARGE CARRIER.

\begin{tabular}{|c|c|c|c|}
\hline & $\begin{array}{l}\text { Electrical } \\
\text { efficiency }\end{array}$ & $\begin{array}{l}\text { Operating } \\
\text { Temperature }\end{array}$ & $\begin{array}{l}\text { Charge } \\
\text { carrier }\end{array}$ \\
\hline $\begin{array}{l}\text { Low-Temperature } \quad \text { Proton } \\
\text { Exchange Membrane Fuel Cells } \\
\text { (LT-PEMFCs) }\end{array}$ & $40 \%-60 \%$ & $60^{\circ} \mathrm{C}-80^{\circ} \mathrm{C}$ & \multirow{2}{*}{$\begin{array}{l}\text { Hydrogen Ion } \\
\left(\mathrm{H}^{+}\right) \text {(proton) }\end{array}$} \\
\hline $\begin{array}{l}\text { High-Temperature Proton } \\
\text { Exchange Membrane Fuel Cells } \\
\text { (HT-PEMFCs) }\end{array}$ & $50 \%-60 \%$ & $110^{\circ} \mathrm{C}-180^{\circ} \mathrm{C}$ & \\
\hline $\begin{array}{l}\text { Phosphoric Acid Fuel Cells } \\
\text { (PAFCs) }\end{array}$ & $\begin{array}{l}36 \%-45 \%(85 \% \text { with } \\
\text { cogeneration) }\end{array}$ & $160^{\circ} \mathrm{C}-220^{\circ} \mathrm{C}$ & $\begin{array}{l}\text { Hydrogen ion } \\
(\mathrm{H}+) \text { (proton) }\end{array}$ \\
\hline $\begin{array}{l}\text { Direct Methanol Fuel Cells } \\
\text { (DMFCs) }\end{array}$ & $35 \%-60 \%$ & Ambient $-110^{\circ} \mathrm{C}$ & $\begin{array}{l}\text { Hydrogen Ion } \\
(\mathrm{H}+) \text { (proton) }\end{array}$ \\
\hline $\begin{array}{l}\text { Direct Ethanol Fuel Cells } \\
\text { (DEFCs) }\end{array}$ & $20 \%-40 \%$ & Ambient $-120^{\circ} \mathrm{C}$ & $\begin{array}{l}\text { Hydrogen ion } \\
(\mathrm{H}+) \text { (proton) }\end{array}$ \\
\hline Alkaline Fuel Cells (AFCs) & $60-70 \%$ & Below zero $-230^{\circ} \mathrm{C}$ & $\begin{array}{l}\text { Hydroxyl ion } \\
(\mathrm{OH})-\end{array}$ \\
\hline $\begin{array}{l}\text { Molten Carbonate Fuel Cells } \\
\text { (MCFCs) }\end{array}$ & $\begin{array}{l}55 \%-65 \% \text { ( } 85 \% \text { with } \\
\text { cogeneration) }\end{array}$ & $600^{\circ} \mathrm{C}-700^{\circ} \mathrm{C}$ & $\begin{array}{l}\text { Carbonate ion } \\
\left(\mathrm{CO}_{3}\right)_{2-}\end{array}$ \\
\hline Solid Oxide Fuel Cells (SOFCs) & $\begin{array}{l}55 \%-65 \% \text { ( } 85 \% \text { with } \\
\text { cogeneration) }\end{array}$ & $800^{\circ} \mathrm{C}-1000^{\circ} \mathrm{C}$ & $\begin{array}{l}\text { Oxygen Ion }\left(\mathrm{O}_{2}-\right. \\
\text { ) }\end{array}$ \\
\hline $\begin{array}{l}\text { Proton Ceramic Fuel Cells } \\
\text { (PCFCs) }\end{array}$ & $55 \%-65 \%$ & $700^{\circ} \mathrm{C}-750^{\circ} \mathrm{C}$ & $\begin{array}{l}\text { Hydrogen ion } \\
(\mathrm{H}+) \text { (proton) }\end{array}$ \\
\hline
\end{tabular}




\begin{tabular}{|l|l|l|l|}
\hline Zinc-Air Fuel Cells (ZAFCs) & $30 \%-50 \%$ & Below zero $-60^{\circ} \mathrm{C}$ & $\begin{array}{l}\text { Hydroxyl ion } \\
(\mathrm{OH})-\end{array}$ \\
\hline $\begin{array}{l}\text { Direct Borohydride Fuel Cells } \\
\text { (DBFCs) }\end{array}$ & $40 \%-50 \%$ & $20^{\circ} \mathrm{C}-85^{\circ} \mathrm{C}$ & $\begin{array}{l}\text { Sodium ion } \\
(\mathrm{Na}+)\end{array}$ \\
\hline $\begin{array}{l}\text { Direct Formic Acid Fuel Cells } \\
\text { (DFAFCs) }\end{array}$ & $30 \%-50 \%$ & $30^{\circ} \mathrm{C}-60^{\circ} \mathrm{C}$ & $\begin{array}{l}\text { Hydrogen ion } \\
(\mathrm{H}+) \text { (proton) }\end{array}$ \\
\hline $\begin{array}{l}\text { Direct Carbon Fuel Cells (DCFCs) } \\
\text { Oxygen Ion } \\
(\mathrm{O} 2-)\end{array}$ & $600^{\circ} \mathrm{C}-1000^{\circ} \mathrm{C}$ \\
\hline $\begin{array}{l}\text { Enzymatic Fuel Cells (BFCs) } \\
\text { Microbial Fuel Cells (BFCs) }\end{array}$ & $15 \%-65 \%$ & $20^{\circ} \mathrm{C}-40^{\circ} \mathrm{C}$ & $\begin{array}{l}\text { Hydrogen ion } \\
\left(\mathrm{H}^{+}\right) \text {(proton) }\end{array}$ \\
\hline
\end{tabular}

\section{APPLICATIONS OF FUEL CELLS IN THE STATIONARY AND PORTABLE FIELDS}

According to [14], it has been noted that fuel cell applications were distinguished as: applications with high power reliability (telecommunication, high technology manufacturing facilities, data processing and call centers), applications with emission minimization or elimination (urban areas, industrial facilities, airports, vehicles), applications for areas with limited access to utility grid (portable applications and remote areas) and applications for biological waste gases management (waste treatment plants). However, in this section, fuel cell stationary and portable applications are reviewed.

\subsection{FUEL CELL APPLICATION IN PORTABLE SECTOR:}

The increasing demand for quality, density and time performance of power supply is the principal driving force in the portable power production market, which includes an increasing number of new products (cassette and mini disc players, laptop computers, cellular phones). In this market there is always a competition between the different technologies, because products must be smaller, cheaper, and lighter, with an increasing number of functions [11]. Moreover, the fields of telecommunications, computers, Internet and social networks have become essential for humans, 
and this implies the need for a fully reliable electricity supply [15]. For all these reasons fuel cells are particularly appropriate as portable power systems due to the fact that they have good potential in terms of energy density, durability, simple design and low cost. A fuel cell can operate as long the fuel is supplied to the device and this can be easily done from a very small and light tank [11]. Portable applications of fuel cells are mainly focused on two main markets, as we can see in (figure 2). The first is the market of portable power generators designed for light outdoor personal uses (e.g. camping and climbing), light commercial applications such as portable signage and surveillance, and power required for emergency relief efforts [6] In fact, fuel cells can provide electrical power in places where the grid connection is not available. For example, in a vacation place outdoors (camping area), the use of a fuel cell for electrical power instead of a diesel generator, avoiding harmful emissions, help to preserve the environment and causes no problems noise to other people in the environment [15]. The second market is the market of consumer electronic devices (e.g. laptops, cell phones, radios, camcorders, i-pods, and basically any electronic device that traditionally runs on a battery) [6]. The modularity and high energy density of fuel cells make them strong potential candidates for future portable personal electronics [7]. Fuel Cells may be also used to provide power as a primary or support system for telecommunications switching nodes, transmission towers, reception or other electronic devices that can benefit from the DC power supplied by a fuel cell [15]. Other rapidly-growing markets in the portable sector include portable battery chargers in addition to miniature demonstration and educational remote control (RC) vehicles, toys, kits, and gadgets by manufacturers, such as Horizon hydrocarbon educational kit [7]. 


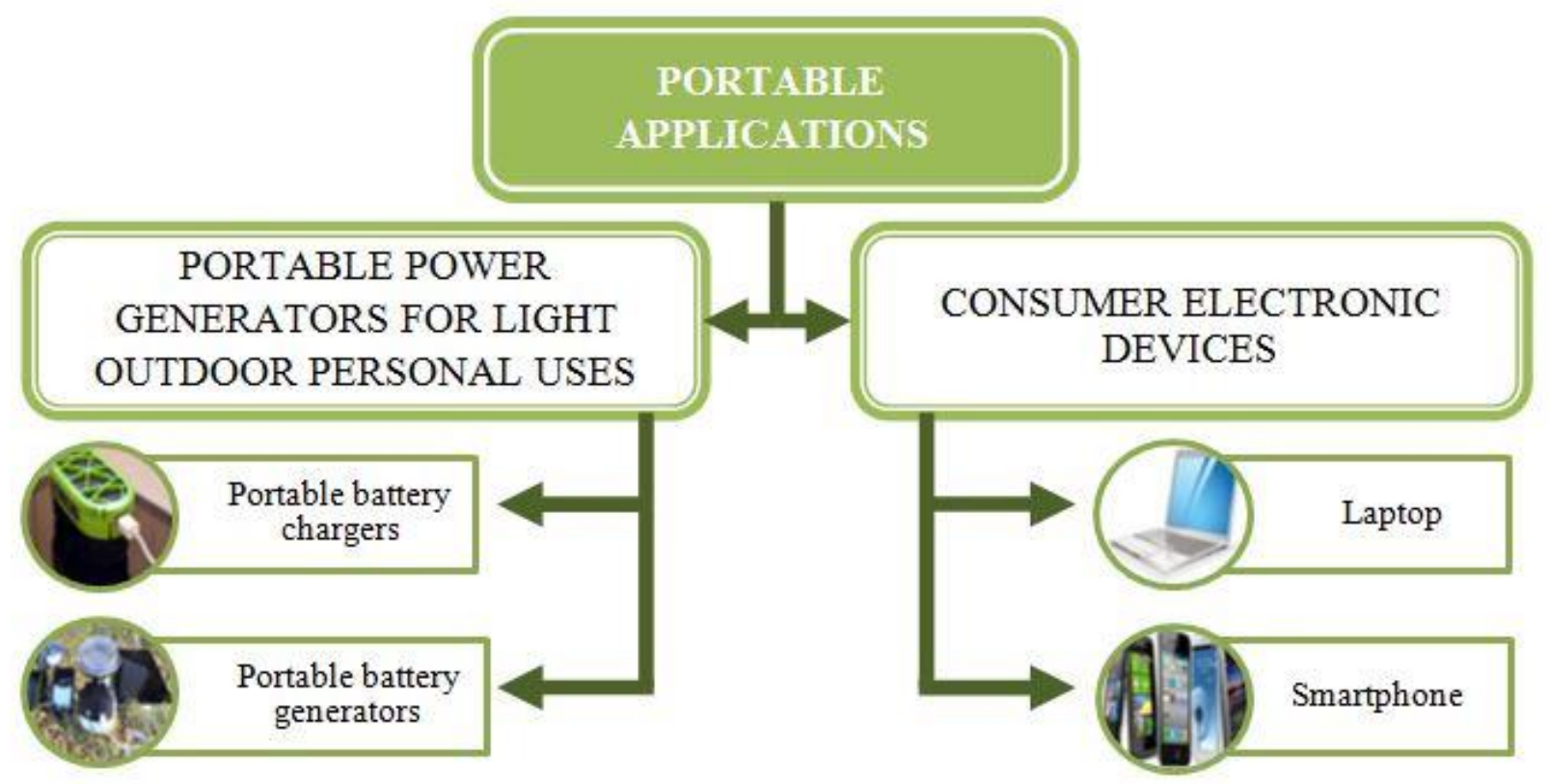

Fig 1. Portable Applications For Fuel Cells.

In particular, there is a growing demand of power systems for portable electronic equipment in the military market $[11,12]$, which means a growing application of portable DMFCs and PEMFCs due to their silent operation, high power and energy density, and low weight compared to current battery-based portable equipment [6]. Moreover, the military market accepts higher prices for the trade-off of better performance and weight [4]. ]. PEM fuel cell power plants offer high efficiency operation. However, the problem with the large PEM fuel cells $(>2 \mathrm{~kW})$ is that they need hydrogen fuel to operate, while hydrogen should be generated from existing logistic fuels $[15,18]$.

Portable fuel cell in 2012 had very high prospects especially after three fuel cell chargers for consumer electronics were launched. Two of the systems could not be launched and they were produced by myFC and Aquafairy. It should be noted that there were still $174 \%$ increase of shipment for fuel cells compared to that in 2011. myFC and Horizon also continued to expend their systems to be easily assessable to consumers by 2013 irrespective of all what they endured in 2012, while Aquafairy changed to building fuel cells for emergency backup power. In 2013, a continued interest in portable fuel cells for consumer electronics was expected but at a slightly reduced level than before as the technology establishes itself against competing batteries. Unit shipments were in 2013 slightly lower than in 2012, at around 13,000 units. In terms of megawatts, the figure for portable fuel cells is small in comparison to other applications, due to the small size 
and capacity of the fuel cell units operating in portable sector. However, the portable fuel cell market can be categorized into four main areas as follows:

- Charging consumer electronics (e.g. mobile phones).

- Auxiliary power units in leisure applications (e.g. camper vans and caravans).

- Military use for soldiers (e.g. borne power and unmanned aerial vehicles).

- Small power levels for educational uses and toys.

There has been strong growth in the shipments of the portable fuel cell sector from $2013-2014$ with annual sales from some manufacturers running in the 10,000 range. This is mainly because of the increase of the consumer products (e.g. mobile phone). Horizon kicked off the commercialization of fuel cell handheld USB chargers in 2011 with their Minipack line. Since then, they have successfully launched their hydropack and Aquipen 180 in 2013 and 2014 respectfully. Both are centered in camping and Caravan markets.

Hand- held mobile devices, show cumulative communicating, computing and entertaining functionalities, with which portable fuel cells can make these devices more secure, convenient and hassle free $[5,19]$. For effective usage of these applications, it is imperative that the charging and power back- up systems of these devices are carefully researched. A practical scenario according to [19] is the third generation (B3G) multimedia phone which requires approximately $3790 \mathrm{mAh}$ per day. Extremely sophisticated high tech electronics like radios, night vision devices, portable computers and personal cooling systems are vital examples. All these devices surely demand sustainable and secure power supply. Reducing the weight of these power sources with ensuring longer operating period is of a vital demand for devices like the mobile notebook personal computer [19]. Table 5 shows the general power demand for some simple portable devices that may require the use of fuel cell. 
TABLE 5: POWER DEMAND FOR PORTABLE DEVICES THAT MAY REQUIRE FUEL CELL [6]

\begin{tabular}{|l|l|}
\hline ITEMS & POWER REQUIRED $(\mathrm{W})$ \\
\hline Cellular phone & 1 \\
\hline Personal digital assistant (PDA) & 1 \\
\hline Notebook personal computer & $20-30$ \\
\hline Flashlights and toys & $1-10$ \\
\hline Tablet personal computer & 10 \\
\hline PlayStation portable (PSP) & 2 \\
\hline Digital multimedia broadcast - receiving (DMB) phone & 3 \\
\hline Iphone & 2 \\
\hline Robot & $10-15$ \\
\hline Digital camera & 1 \\
\hline
\end{tabular}

Portable devices were categorized [20] based on the power demanded, small devices and electronics demanding up to $3 \mathrm{~W}$ of power are classified under one category (e.g. mp3 player, Cameras, etc.), while large personal electronics (e.g. laptops, and printers) requiring up to $30 \mathrm{~W}$ of power are placed in another category. According to [21], the limited progress that has been made in current battery technology has generally failed to cope with the rapid progress achieved in the field of portable electronic devices (PED) fabrication. As a result, some researchers have resorted to other alternatives, including fuel cells [21 -29]. Fuel cells are extremely applicable to everyday life due to some of its advantages like instant recharging via a replacement or a refilled fuel cartridge, highly independency from electricity, long life span, high energy conversion from chemical to electrical efficiency, good weight reduction potential and less contamination and pollution resulted [30, 31]. Fuel cells have no memory effect when they are refueled. According to [32], hydrogen fuel cells are far superior in terms of energy density. For better competition between portable fuel cell and presently widely existing rechargeable batteries, the energy efficiency, energy and power densities as well as cost must be carefully branded to make fuel cell option competitive with batteries.

One the other hand, the general design of a battery is usually simple as compared to hydrogen fuel cell. This is basically due to the presence of fuel hydrogen and oxidant delivery systems, water 
management systems, gas isolation systems and flexible and low loss external electrical access. The miniaturization prospects and subsequent application in miniature portable device is seriously affected by that. However, recent progress made in micro electro-mechanical systems (MEMS) technology and its application in designing other fuel cell component have given rise to the possibility of miniaturizing the fuel cell devices to make them compatible with miniature PED [33 $-35]$.

\subsection{STATIONARY APPLICATION FOR FUEL CELL}

The most common type of fuel cell used in stationary power applications is the PEMFC, but SOFCs, MCFCs, AFCs, and PAFCs are also utilized [6]. In fact, both low and high temperature fuel cells could, in principle, be utilized for stationary applications. While low-temperature fuel cells have the advantage that are usually faster during start-up, high-temperature systems (such as SOFCs and MCFCs) produce heat which can directly be used for other applications, and they can also operate directly on fuels without the external reforming [16], reaching a higher efficiency than low-temperature systems[15]. As can be seen from (figure 5), we can identify two main power plants; large stationary power plant (power output from $300 \mathrm{~kW}$ up to $20 \mathrm{MW}$ ) and small-medium stationary power plants (power output from a few Watts up to $10 \mathrm{~kW}$ for small stationary power plants and from $10 \mathrm{~kW}$ up to $300 \mathrm{~kW}$ for medium stationary power plants) [6]. Moreover, stationary fuel cells, depending on their features, may be used for many applications, either as the primary power source instead of the grid, or in places where the grid cannot reach (remote area power supply-RAPS), to provide supplemental power in hybrid power systems with photovoltaics, batteries, capacitors, or wind turbines, providing primary or secondary power (distributed power or CHP generation), or as a backup (emergency back-up power supply-EPS or UPS) [6- 8]. 


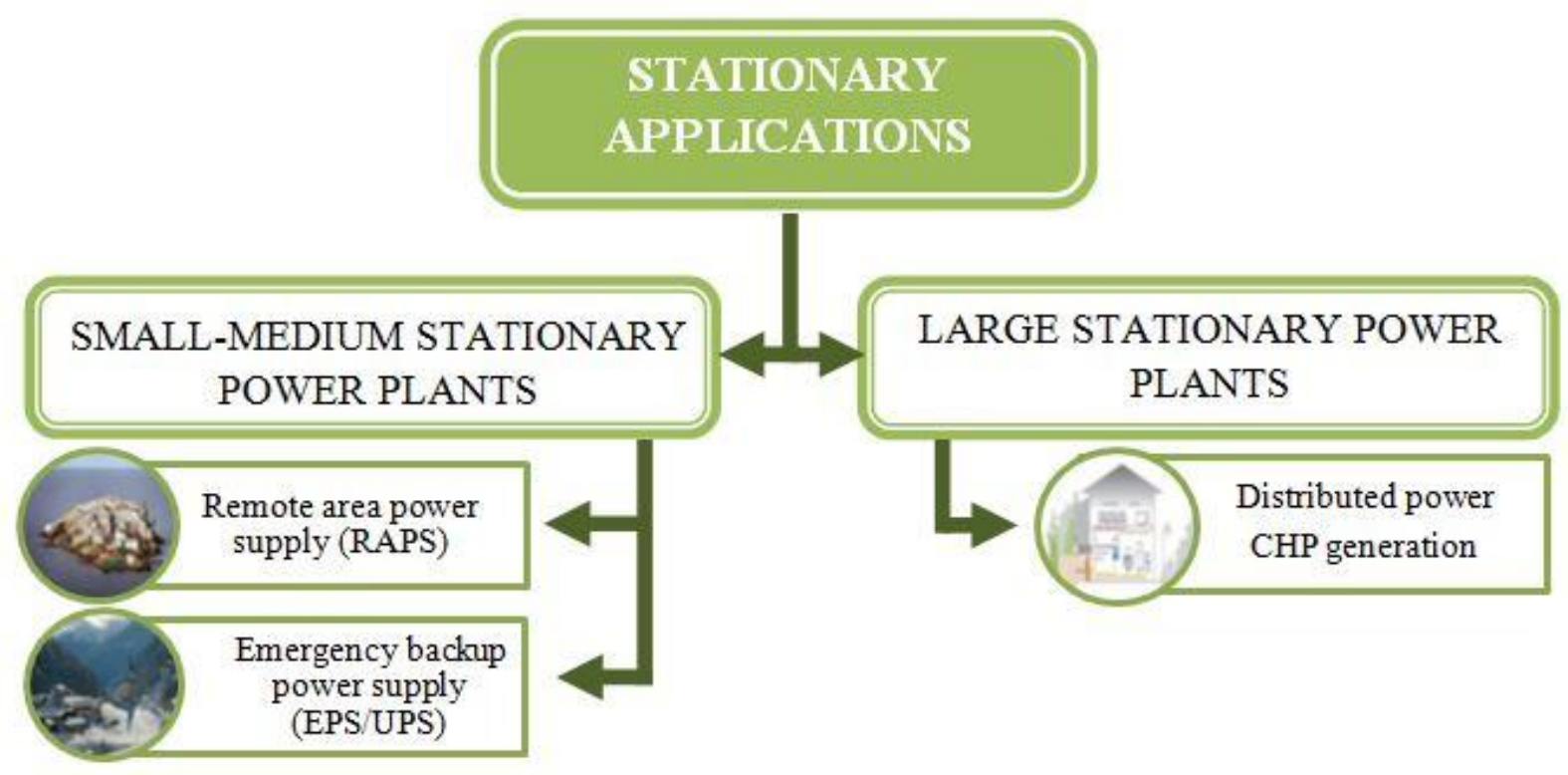

Fig 3. Stationary Applications For Fuel Cells.

\subsubsection{LARGE STATIONARY POWER PLANTS}

Fuel cells strategy can help to make the shift from large centralized power generation to decentralized distributed generation. Due to their static nature, lower emissions, exceptional loadfollowing, and high efficiency, fuel cells could be used for residential electric power or CHP distributed generation either on a household basis or on a larger residential blocks basis [5]. Combined Heat and Power Systems offer increase energy efficiency through the use of both electric and thermal energy. The heat produced can be used for space heating or other various purposes [36]. Proton exchange membrane fuel cells (PEMFC) and phosphoric acid fuel cells (PAFC) are widely used for CHP applications, in particular for household basis CHP generation [6], but they work at low temperatures such as less than $100^{\circ} \mathrm{C}$ and $200^{\circ} \mathrm{C}$, so that both of them need an external fuel reformer in order to use fuel other than pure hydrogen and they have a low tolerance for $\mathrm{CO}$ (the product of natural gas reforming), and they exhibit operation with electrical efficiencies only in the low 30\% range [37]. For these reasons, high-temperature fuel cells are more suitable for the larger residential block basis CHP generation [10], and in particular, for these applications, SOFC are the best candidates. At a higher temperature, SOFC system has greater advantages for the combined supply of heating and electricity over these technologies [37]. Fuel cell systems used for CHP generation could be designed to be either grid-independent or grid- 
assisted. The first case is more complicated with higher cost, as the system will have to meet dynamic load fluctuations, but it is possible to solve the problem over sizing the fuel cell system and integrating it with battery-banks or ultra-capacitors. On the other hand, gird-assisted systems export electricity to the grid during low load demands and import electricity from the grid during peak load demands. For both cases, a thermal storage mechanism is required for an effective CHP system [37].

\subsubsection{Medium and small stationary power plants}

The range of applications of medium-small power plants is very large. They are designed primarily for a combined supply of electric power and heat to individual structures of different sizes: individual cottages, administrative and office buildings and hospitals [12]. Fuel cell-based power plants of small power are built to supply electric power to individual residential or administrative quarters or to remote individual power costumers [12]. The main applications in this field concern plants for electricity production and co-generation for buildings, and for industrial and commercial applications. In parallel to the above listed advantages, other significant features of these plants are the production of premium quality power, the possibility of using an independent source that can operate for "onsite" production or as a continuous power backup or as an uninterrupted power supply (EPS) [11]. Most fuel cells used for low-power plants were PEMFCs. The Japanese company Ebara Ballard developed a 1-kW power plant for combined heat and power production. The unit was designed to operate for 10 years, in accord with requirements set by the Japanese government. A similar unit is also designed for an operating time of 10 years was developed by the Japanese company Fuji electric. These units cost $\$ 12.000$ to $\$ 16.000$ [12].

Due to their high energy and power densities, high modularity, longer operation times, compact size, and ability to operate under unkind ambient conditions, fuel cells are becoming an encouraging alternative for batteries in the electro power system (EPS) market, especially in the telecommunications market, with PEMFCs and DMFCs as the dominantly-chosen fuel cell types [5]. Due to the fact that the EPS market requires high reliability but not necessarily high operational lifetimes, fuel cells found EPS to be one of its most successful markets, such as data centres, banks, and government agencies. Other users who can use units of this type are the surgery wards in hospitals, the computer units in traffic control and financial institutions, and the systems of emergency lighting in public spaces $[7,12]$. 
Another important application of small power units is in remote-area power supply (RAPS). In grid-isolated locations, such as islands, deserts, forests, remote technical installations, and remote research facilities, providing power could be a problem. All of these locations and other more fall under the remote-area power supply (RAPS) category [7]. An interesting project concerns plans to use fuel cells in the Antarctic base on Bechervaise Island. This project, supported by a grant of $\$ 600000$ from the Australian government, involves the production of hydrogen by electrolysis with wind energy and its use in low-power fuel cell units producing electric power and heat [12].

The limited availability of fossil fuels is gradually making renewable energy sources like wind and solar power as promising alternatives due to the effect the have on the environment as well. The inconsistencies in terms of their (renewable) energy production during the day or at some point in time in the year due to meteorological conditions hinder their progress as an energy generation medium. It is therefore imperative that energy storage mediums are highly explored so that during such unforeseen occurrences, production can still continue $(38,39)$. Through a chemical reaction with oxygen from a fuel cell, hydrogen being an energy carrier can be converted into electricity. Therefore, coupling energy storage systems with renewable energy sources through an electrolyser, that can transform electric energy into hydrogen chemical energy, is considered as a high sustainable process of production and exploitation of renewable energies (40).

The advancement of stationary fuel cell systems have been championed by a several developed countries. Notable among these countries are USA, Canada, Japan and South Korea as well as Europe. Fuel cell Energy, Accumentris, ClearEdge and Bloom Energy are some companies well known around the world for the production of stationary fuel cells (41). Some giant companies in the North America like Panasonic, Toshiba and JX in Japan; Posco in South Korea are all noted for producing fuel cells for stationary applications. Others like Topsoe Fuel cells, Intelligent Energy, Baxi Innotech, Dantherm Power, Hexis CFCL, Cere Power and Elcore remain some companies in Europe know for production in the stationary fuel cell application industry. The support from governments has been one of the active reasons for the progress of stationary applications endured so far.

According to (42), the data received in 2013 indicated the 24,000 unit of stationary application was shipped making $125 \mathrm{MW}$ of power capacity. Comparatively it represented an increment of $50 \%$ in 2012 and $53 \%$ in relation to that of 2011 . This increase of percentage was less than that 
experienced between 2010 and 2011. The massive progress in the shipments of stationary fuel cell systems reflects the growth of installations of micro - CHP units (from less than $1 \mathrm{kWe}$ to several kWe). Under the Ene- Farm programme, a total of about 40,000 installations were made in Japan between 2009 to the end of 2012. It was also anticipated that between 35,000 to 40000 was to be installed by 2013 as well (43). With this fast rate of installations, Japan is likely to meet its target of 1.4 million micro - CHP fuel cell systems by 2020 and 5.3 million by 2030 (44). Even though the progress has not been that rapid in other parts of the world, Germany by 2012 had installed more than 300 units of microchips under the Callux programme. Fuel cell and hydrogen joint undertaking supported demonstration projects are considering installing more units: the ene-field consortium is also installing 1000 fuel cell micro - CHP units across twelve European countries (45). SOFT - PACT is also undertaking its second phase with up to 100 installations projects (46). The North America, Europe and South Korea has also seen experienced some level of growth in the installation of large sized stationary fuel cell systems though it's been quite slow with units of hundreds kWe to MWe, being installed.

A number of operators in North America have received lots of MCFC and SOFC from both Fuel Cell Energy and Bloom Energy respectively for Pepperidge Farm and Central Connecticut State University, both in Connecticut, USA [47]. By the end of 2013, an announcement was made by Bloom energy, that $100 \mathrm{MWe}$ of its energy servers had been installed in the USA (48). The largest fuel cell park has also been completed in Hwasung City in South Korea with a total generating capacity of 59 MWe.

\section{CHALLENGES AND ADVANCES IN STATIONARY AND PORTABLE FUEL CELL APPLICATIONS}

Every emerging technology is bound to facing obstacles normally described as challenges and Fuel Cell irrespective of the massive developmental progress still experiences some of these setbacks. Some of the challenges could be solved gradually with time but others would demand a radical approach to speed up the developmental process in order to actively compete with others on the market. Below are some major challenges and a few solution to both the portable and stationary fuel cell industry. 


\subsection{PORTABLE APPLICATIONS}

Challenges of fuel cells for portable power include reducing cost (mainly by reducing catalyst loading), increasing efficiency (by reducing fuel crossover and increasing catalyst selectivity), and reducing the size of the hydrogen storage system. Portable power R\&D includes the development of electrodes with higher activity and selectivity, reduction of methanol crossover, and decrease of the whole system volume and weight. Total life cycle efficiency improvement would have a positive impact on emissions reduction during operation. Flexible fuel capability (e.g., ethanol, butane), based on renewable fuels is known to be attractive in this sector.

Although fuel cells and energy storage systems (ESS) have been considered as future energy conveniences, they have not been widely employed because their structures such as bipolar plates (BP), endplate (EP) or flow frames (FF) are made of either brittle graphite, weak polymers or ceramic coated stainless steel to meet the requirements of high electrical conductivity under strong acid environment in most situations [49]. Reduction in device size and increasing demand for high power density are some important parameters that the development of new generation PEDs is anticipated to meet. Implantable applications and low power MEMS can use the power delivered from hydrogen fuel cells from $\mu \mathrm{W}$ to $\mathrm{mW}$ range. A major challenging factor hindering the advancement of hydrogen fuel cell power systems particular in portable applications is the hydrogen storage. Ammonia borane $\left(\mathrm{AB}, \mathrm{NH}_{3} \mathrm{BH}_{3}\right)$ is considered to be a promising hydrogen storage material as it contains $19.6 \mathrm{wt} \%$ hydrogen. It is difficult, however, to release hydrogen from $\mathrm{AB}$. Catalytic hydrolysis and heat generated by additional reactive mixtures are usually employed, but these methods have disadvantages that limit their use for portable applications. An investigation has indicated [50] how hydrogen could be released without using any catalyst. Nano - aluminum $\mathrm{nAl} /$ water was used which provided heat for the $\mathrm{AB}$ dehydration and released an additional hydrogen from the water that was used. The result of the research remarked the effect of hydrogen storage and release on the portable fuel cell industry.

Weight, volume, efficiency, safety and the cost are important considerations to be made during the design of storage facility for hydrogen storage. Hydrogen fuel can be stored in pressurized containers or within chemicals or solids capable of reversible absorption/ desorption of hydrogen with low energy exchange. The development of a safe and portable power source with high gravimetric and volumetric energy densities is a challenge of ongoing importance. For military 
and soldier-born applications, the U.S. Department of Defense Operational Energy Strategy report cites reducing fuel demands, expanding energy storage and conversion options, and improving energy security as being critical to national security. According to the report by [51], there is a significant need to lighten the load (reduce mass) that soldiers are required to carry. Energy storage and power requirements can be expected to increase with advances in electronics, sensors and communications equipment [53].

Reducing the general mass of the present power sources remains one of the reasons that is urging the fuel cells application. This phenomenon is possible due to chemical energy stored in a number of fuels. According to figure 3, the fuel cell system mass has a base line which is offset by the large specific energy of the fuel. As the mission length and energy needed increases, the specific energy of the fuel can also lead to a net mass savings compared to other portable power sources like batteries. Irrespective of the chemical energy stored in fuel, converting the energy into a usable (electrical) form can be challenging. Additional balance of plants is sometimes needed during the conversion process which in effect increases the weight, size and parasitic losses. Portable applications demand simple approaches in making them work effectively. Some factors that are considered when selecting fuel for any portable device is whether the fuel is safe to use, safe to handle, storable, transportable, cost effective, and have large gravimetric and volumetric specific energies (i.e. high energy densities). The fuel requirement is also highly dependent on the system design. Due to these factors, a number of portable fuel systems rely on alcohol fuels which involves using direct and reformed methanol, ethanol and sometimes very large alcohols [54- 56]. Such fuel offers logistical advantages whiles providing large energy densities due to their stabilities in liquid forms [56-58]. 


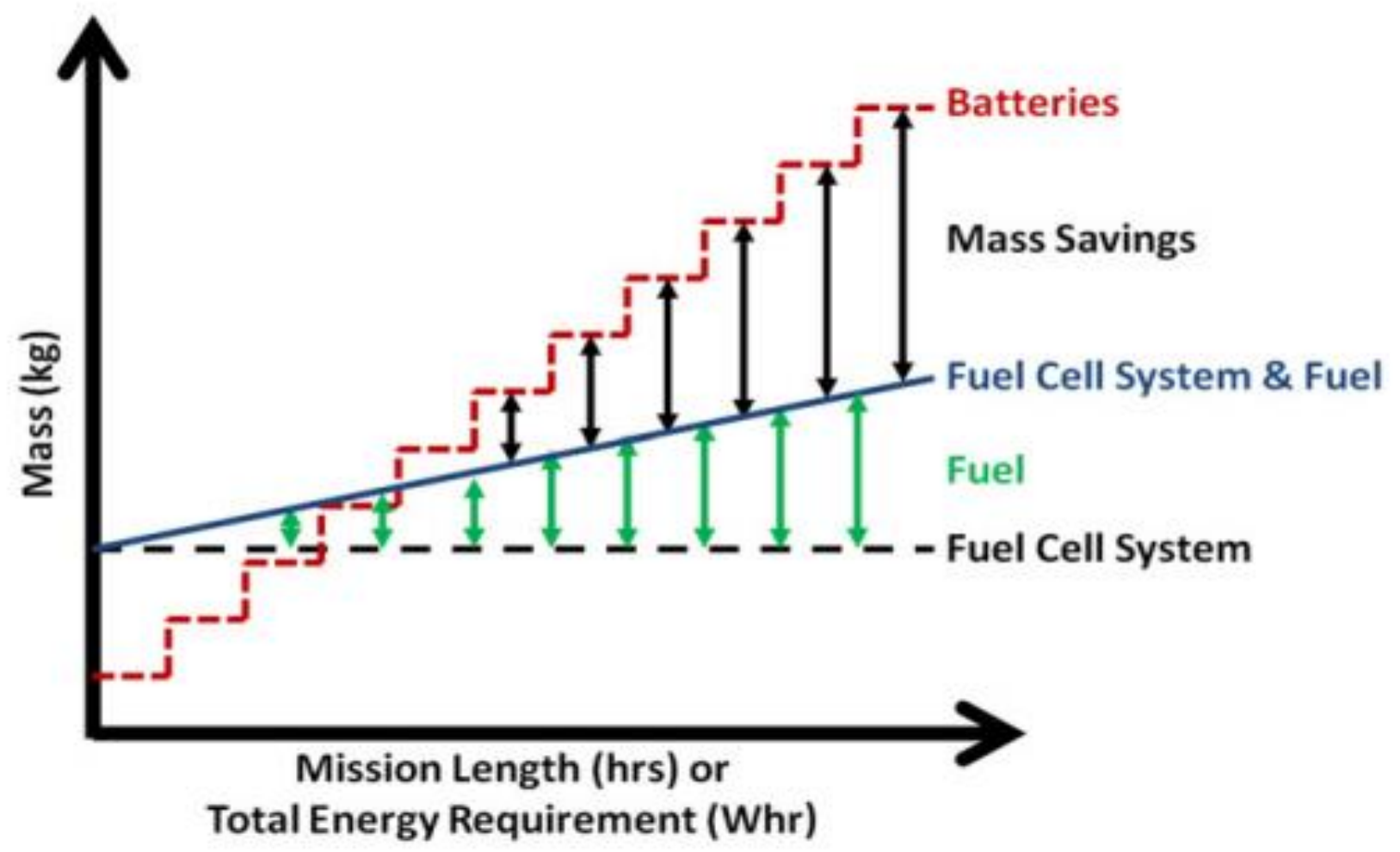

Fig 4: The mass of energy storage and conversion materials is plotted as a function of mission length, or mission energy requirement (65).

An investigation on nitrogen bearing compounds (e.g. hydrazine hydrates) has also been proposed as well as that of metal hydrides for portable applications $(59-61)$. Alane (Aluminum Hydride, AlH3), was also carefully studied as a hydrogen storage material for use in portable applications by (62). Normally Aluminum hydride goes into an endothermic dehydrogenation process through heating. It further undergoes an endothermic reaction through dehydrogenation process; decomposing to hydrogen $(\mathrm{H} 2)$ and Aluminum. Alane provides a reasonable volumetric hydrogen capacity at a density of (1480 kg m3 ) with a gravimetric H2 capacity of greater than 10\%wt (63); a larger volumetric hydrogen capacity than liquid H2 (63). Alane has its own disadvantages as well; the large hydrogen fugacity of Alane prevents it from being thermodynamically stable at room temperature. Moreover, only metastable polymorphic phases of Alane can be formed from applications near ambient conditions (64). It is possible for a metastaABble Alane to undergo a controlled thermal dehydrogenation under normal operating conditions. 
There has been also a rapid improvement in the usage of Alane as Reilly et al (65) investigated using Ti doped $\mathrm{Al}$ powder and various amines to reversibly form $\mathrm{AlH} 3$ - amine adducts under modest H2 pressures $(65-70)$. The risk associated with Alane remains the major concern hindering its' patronage in portable fuel cell applications. This is normally as a result of over pressurization. It's a condition where the hydrogen formed from the dehydrogenation process exceeds the pressure the system can handle; either in a storage vessel or as it is fed to the fuel cell.

Insufficient usage of fuel during operation process could lead to serious scenarios. Situations where Alane fuel is stored at a sufficiently elevated temperature could all lead to such a phenomenon. A pressure relief is often used to seal the fuel side in most portable applications. To both safely operate and maximize the system's energy density, excess $\mathrm{H} 2$ should not be purged on a regular basis. This presents a challenge because $\mathrm{H} 2$ has a large specific volume of $11.9 \mathrm{~m} 3 \mathrm{~kg} 1$ at ambient conditions. If it is not properly controlled and/or a runaway condition is encountered, the $\mathrm{H} 2$ pressure can cause a catastrophic failure. With these concerns, theory was developed and applied to explore Alane as a $\mathrm{H} 2$ storage material for a portable, low temperature fuel cell system by (50jmo). The study demonstrated the benefits of using an Alane as a $\mathrm{H}_{2}$ storage media for a portable fuel cell system. A significant portion of the work was directed towards highlighting the risks as well. The most significant were those associated with an over-pressurization of the $\mathrm{H}_{2}$ storage vessel. Such a failure could occur due to a disruption within the fuel cell system or a change in conditions. Also of concern with the use of Alane was that it is metastable in the vicinity of ambient and dehydrogenation conditions. If it is sufficiently perturbed, it could lead to a catastrophic event. For military applications there is prospect of projectiles, crushing, and extreme operational environments that raise concern.

One major factor hindering the commercialization of fuel cells in portable applications is developing low - cost material to make it cheap and fairly affordable (71). The cost of a fuel cell is highly dependent on the Membrane electrode assembly (MEA) components including the polymer electrode membrane, catalyst and the gas diffusion layer as this form about $40-50 \%$ of the cost of a fuel cell. About one - third of the stack cost is contributed by Pt alone (72) though this has been reduced in the past few years in 2008 where it represented over half of the cost (73). Nafion membranes which are a product from DuPont normally cost US\$ 800m-2. This therefore makes the MEAs the single largest contributor of the total cost of the fuel cell. Using hydrogen in 
fuel cells is more efficient when compared to traditional technology leading to higher quality of energy with lesser waste products. The higher efficiency of the fuel cell does not always presume the initial cost being higher as well. It is therefore imperative that for PEMFCs to gain solid grounds and compete with other available power sources, its capital cost must reduce as well $(74,75)$. According to $(76)$, if the cost of other components of the fuel cell is also reduced and can bring the overall cost down toward commercial cost, it will help in achieving the main performance goal. Current research and investigations in the fuel cell industry is geared towards developing alternative cost effective and efficient membrane as well as a catalyst material. This also involves using PEM materials instead of the traditionally used high cost Nafion membranes. Other researches include using other catalysts materials in place of traditionally used high cost and limited abundance platinum metal (77 - 84).

The energy and power density of the device should generally be high for most portable devices. $\mathrm{Li}$-ion batteries supply approximately $200 \mathrm{Wh} \mathrm{kg}-1$ as its power density. This means for hydrogen power cells to be able to compete with others already in the market, it must generate a higher power density. A high reaction rate at the electrodes and proton transfer rate across the PEM is needed to make this happen. Hydrogen fuel cell uses Nafion membranes as PEMs. The main function of PEM is to transport protons generated in the anode chamber of the fuel cell to the cathode chamber while keeping the reactants and products of one chamber of the fuel cell to the cathode chamber. A perfluorosulfonic acid membrane can attain a high level of proton conductivity (i.e approximately $0.1 \mathrm{Scm}-1$ ). This demands $100 \%$ hydration for this to materialize and note that this is a state of the art Nafion. This condition affects the hydrogen fuel cells from operating at high temperature $\left(>60-80^{\circ} \mathrm{C}\right)$ at normal atmospheric pressure. It therefore requires fuels that are fully hydrated that is hydrogen 116 Compendium of Hydrogen Energy and oxygen/air, in order to function properly. Hydrogen fuels are often generated from hydrocarbons (such as gasoline and natural gas) reforming using water gas shift reactions but they are normally contaminated with carbon monoxide (CO) constituting 1\%. The gas produced (CO) causes poisoning at the anode precisely at the low operating temperature of the cell. In order to prevent the $\mathrm{CO}$ poisoning a high temperature of approximately $100^{\circ} \mathrm{C}$ is required and also to speed up the reactions at the anode kinetically. Again when the operating temperature is high the importance of water management is eliminated. Therefore, development of alternative PEMs that require low hydration conditions for achievement of high proton conductivity and $\mathrm{CO}$ tolerant catalysts are 
required in order to increase the efficiency of hydrogen fuel cells toward practical portable applications (84).

\subsection{STATIONARY APPLICATIONS}

The vision to support the European Union's 20-20-20 targets for emissions, efficiency and energy sources is very important and stationary fuel cell systems can be a possible solution to meet that target. The important role stationary fuel cells systems can play in the energy industry is dicey as a number of factors should be carefully considered. These factors usually forms the building block or perimeter hindering the further progress of this useful technology. Cost, environmental benefits of reduced emissions, quiet operations relatively and the possibility of being autonomous from mainstream power suppliers for end users remain some advantages of the stationary fuel cell systems if well explored. These merits could be categorized under three main areas; reliability, durability and affordability. Fuel cell systems should be able to be reliable enough to supply power continuously just like the centralized power grids, they should have an operational lifetime equal to existing that of domestic and commercial boilers and generators, and must be competitive in terms of the power being delivered as well as the heat. Stationary fuel cell systems over the past few decades have been able to live up to expectations in terms of reliability and durability though some researchers may not agree in totality. The most challenging area in this field is related to the cost though the world at large is equally making some progress (85) to make it cheaper and affordable.

Cost undoubtedly plays a very important role in the commercialization of stationary fuel cell systems worldwide. The cost of stationary fuel cell systems operating currently is normally between 25000 - 40000 euros per kWe (85). An investigation performed by NREL in the USA indicated that the prices of 249 units either completed or to be installed in the USA to the end of 2012 or early 2013 are ranged between 3000 and 21,000 \$/ kWe (2200 - 15,500 euros /kWe). These are prices and not costs and are without incentives. With incentives ranging from 2000 to $5500 \$ / \mathrm{kWe}$, the prices fall to $\$ 1000$ to $\$ 19,000 / \mathrm{kWe}(41)$. The size and maturity of the units depicts the cost noting that smaller units are more expensive than larger units on a cost/kWe basis, while the cheaper in terms of cost per kWe installed are the larger fuel cell units. An evidence recently suggested that units produced by Fuel Cell energy and ClearEdge are increasing economically without any form of public support. These units could be best used for CHP 
applications for large buildings. Quite a number of them is recently being used in Europe including London (82). However, the cost/price of smaller fuel cell systems in the kWe range is higher in relation of that of the larger units. The Ene - farm project for residential units in Japan was between 20000 to 25000 euros $/ \mathrm{kWe}$ range. It is evident that there is a market, and a growing market, for stationary fuel cell systems. To achieve mass market success for the commercialization of stationary fuel cell systems, an extra emphasis should be placed on cost targets. Domestic micro CHP products normally have these targets already developed and usually set by the public sector. A target set by METI in Japan as at 2008 aims at micro - CHP fuel cell systems meeting an estimated cost of 3700 - 4450 euros between 2020 and 2030 (87-88). The Department of Energy in the USA also anticipate the cost of $2 \mathrm{kWe}$ unit being $\$ 1000$, whilst the European FCH JU has a target of V5000/kWe plus household heating by 2020 as set out in the revised Multi-Annual Implementation Plan (89-92).

A major means of transforming the stationary fuel cell sector is to support the industry with funds from the public sector. This could be done in the form of capital subsidies as done in Rhine Westphalia in Germany (93). It can also be done through capital support and feed in tariff pricing as seen in South Korea (94) or what is practiced in the United States where there are other incentives usually at the State level with the incentives varying up to $\$ 5500 / \mathrm{kWe}$. This approaching is one of the fastest way of reducing the general cost and higher prices of stationary application system and also led in better competition with other energy systems. The Ene - Farm micro - CHP system received a total support of about 3300 euros forming one fourth of the total unit price with tax being inclusive (94). The regions or cities also have additional subsidies as well in Japan to support stationary fuel cell systems as seen in Nagoya (95). Public support is an important early market incentive for stationary fuel cells systems, be this in the form of capital subsidies like what was experienced in South Korea [92].

The long term success of stationary fuel cell systems will depend upon on costs reductions, and more innovative marketing activities. Deployment of small number units of stationary fuel cell systems is very important even though the main objective is to hit the large market. The commencement of any new technology usually starts with an early market. This is specifically very small units are deployed and developers receive experience and also deal with issues surrounding such technologies. It therefore can move down the cost reduction curve. The 
deployments of stationary fuel cell systems during this early markets periods is usually achieved considering the help of a number of factors. With all new technologies and products there are always 'early adopter' style customers who are willing to purchase products or services above the prevailing price offered by competitive products or solutions.

In addition there are early markets where due to specific local circumstances the proposition of a new product or solution need not be as stringent as in other markets. The best example in recent years of early markets for fuel cell and hydrogen technology has been the work undertaken by the UK H2 Mobility project [97]. This public-private collaboration is examining the ways and means of achieving commercialization of fuel cell vehicles in the UK. Using surveys and focus groups the project identified segments in the UK car buying population that are sufficiently interested in fuel cell vehicles to be willing-to-pay a premium price for a fuel cell vehicle. Two sectors were identified: 'Innovative Greens' and 'Well off Technology Enthusiasts'. Although representing only about $10 \%$ of the car buying public they nonetheless represent a potential early market for fuel cell vehicles in the UK (95). A similar activity is required for the stationary fuel cell sector. It is apparent that although costs are important, there are early markets where the total value proposition of stationary fuel cell systems is attractive to end users. Amongst the various reasons reported for customer purchase decisions are the 'green credentials' of lower emissions and higher fuel efficiencies, whilst more practical operational considerations, most notably autonomy and reliability of supply are as equally, if not more important, and customers are willing to pay a premium, albeit it may not be very great.

To be able to identify the early deployment opportunities properly by developers, it's very important to consider market segmenting. This is where the stationary fuel cell system is attached to another product being sold on the market to cover the cost of the stationary fuel cell. An example is attaching the system to a building product being sold on the market as seen in the Ene - farm project in Japan although subsidies are available for the sale of a residential CHP fuel cell systems. A number of sales are being made when the two products are sold together instead of selling them separately as it would have been done under normal circumstances. This makes the building more environmentally friendly attracting a number of customers. Again in London, planning authorities consider a building to be favorable only if it's green. Several large commercial developments in London in the past few years have been constructed with large fuel cell CHP units incorporated 
[98]. An office user intending to rent a place in central London as well as a retailer was attracted to the shop due to the Quadrant development in the Regent Street area of London according to (99). Most corporate users have the responsibility of protecting the environment for both their customers and their own employees hence this would make more corporate users become attracted to the project.

Again the autonomy of power and heat that fuel cell systems can provide to end users remains another challenge which when improve can make stationary systems become very attractive. Since stationary fuel cell systems may have some independence from the usual power grid, in situations where there are blackouts end users may not experience it that much as it has been proven to be very reliable in terms of heat and power. There are serious cost implications whenever there is a blackout either on the part of the domestic users or loss of productive time for commercial and industrial users (95). Similarly stationary fuel cell systems offer end users the prospect of better control over their energy costs. As energy costs continue to rise, for example in Europe, the attractiveness to large energy users of autonomy from the grid is likely to prove increasingly attractive. These examples of early market deployment demonstrate the importance of identifying those opportunities where the value of a stationary fuel cell system to an end user can be enhanced through additional benefits over and above simple cost competitiveness, or where the fuel cell system is part of a larger offering (99).

\section{SUMMARY}

In a nut shell, the future prospect of fuel cells replacing traditional fossil fuels is very bright though the acceptance of this good and innovative technology is still undergoing some setbacks due to the factors stated above in this paper. The challenges faced by the entire industry cuts across through the 3 main sectors. Cost reduction is the main challenge hindering the progress of the industry.

Some of the challenges would demand stake holders educating the end users about the benefits of championing this cause and researchers doing extensive work to model new and advanced technology to make it cheap and affordable in cost but very durable with a longer life span. Supporting the sectors with funds from government subventions could be a major boost to the industry particular in the stationary sector as experienced in Rhine - Westphalia in German. Feed

in Tariffs pricing could be structured by the government as seen in South Korea and even the United States. The portable sector can also become extremely viable if the cost is actual reduced 
by reducing the catalyst loading, increasing the efficiency through the reduction in fuel crossover and increasing the catalyst selectivity. Again reducing the size of the hydrogen storage system are some pragmatic ways of actually making the fuel cell appealing to consumers and attractive too as it being bulk usually do not encourage people to patronize the product. This in effect means reducing the whole systems weight and volume. If all these recommendations are carefully considered and put into action, fuel cells can actively compete with other storage devices or probably become the best among its competitors. It is also worth noting that (100) argued that the real barriers to fuel cell scaling-up are neither the development of a hydrogen fueling infrastructure and market nor issues with hydrogen, but challenges within the fuel cell itself. His research further stipulated that reliability of fuel cell for end users was more important compared to its durability yet this serious issues received little attention by the entire research community around the globe. Problems in relation to uniform flow distribution in the fuel cell was gradually being curbed due to the advancement of theoretical solutions in the fuel cell industry hence cost, durability and reliability of fuel cell has improved tremendously in recent times. Failures of most fuel cell stacks were as a result of uneven flow distribution in the cells. Integrating fuel cell with other technologies in the field of science like material, process control and catalyst is one of the important was of improving the viability of the fuel cell industry. These simply iterates that building a new business model, experiments, chemistry, materials, control, design and manufacturing can create technical measures for substantial improvement of durability, reliability and robustness, while the development of markets will result in cost reductions, which would substantially accelerate the commercialization of fuel cells in the near future (100). 


\section{REFERENCES}

1. A. Alaswad, M. Dassisti, T. Prescott, A.G. Olabi. Technologies and developments of third generation biofuel production. Renewable and Sustainable Energy Reviews 51 (2015) $1446-1460$.

2. Intergovernmental Panel on Climate Change, 2011. Renewable Energy Source and Climate Mitigation. Special Report on Renewable Energy Sources and Climate Change Mitigation

3. Carter, D., Wing, J., 2013. The Fuel Cell Industry Review 2013. FuelCellToday Johnson Matthey PLC.

4. Hart, D., Lehner, R., Lewis, R.., 2014. The Fuel Cell Industry Review, 2014.

5. Kundu, P. P., Dutta, K. Hydrogen fuel cells for portable applications. Compendium of hydrogen Energy, 2016 Pages 111 - 131.

6. Coleen S. Spiegel, Designing \& Building Fuel Cells- $1^{\text {st }}$ edition, 2007

7. Omar Z. Sharaf, Mehmet F. Orhan, An overview of fuel cell technology : Fundamentals and applications, $13^{\text {th }}$ February 2014

8. A. Alaswad, A. Palumbo M. Dassisti, A.G. Olabi. Fuel Cell Technologies, Applications, and State of the Art. A Reference Guide. Accepted in Reference Module in Materials Science and Materials Engineering (MATS). 2016 Elsevier Inc. All rights reserved.

9. Umberto Lucia, Overview on fuel cells, $20^{\text {th }}$ October 2013

10. NASA.gov, 2015. Summary: Space Applications of Hydrogen And Fuel Cells. http://www.nasa.gov/topics/technology/hydrogen/hydrogen_2009.html (Accessed: $1 / 11 / 2015)$

11. G. Cacciola, V. Antonucci, S. Freni, Technology up date and new strategies on fuel cells, 2001

12. Vladimir S. Bagotsky, Fuel Cells: Problems and Solutions, 2009

13. James Larminie, Andrew Dicks, Fuel Cell System Explained-2 ${ }^{\text {nd }}$ edition, 2003

14. S. Mekhilef, R. Saidur, A. Safari, Comparative study of different fuel cell technologies, 21 October 2011

15. J.M. Andu' jar, F. Segura, Fuel cells: History and updating. A walk along two centuries, $25^{\text {th }}$ March 2009

16. L. Carrette, K. A. Friedrich and U. Stimming, Fuel Cells : Fundamentals and Applications, 2001 
17. Ashok S. Patil, Terry G. Dubois, Nicholas Sifer, Elizabeth Bostic, Kristopher Gardner, Michael Quah, Christopher Bolton, Portable fuel cell systems for America's army: technology transition to the field, $2^{\text {nd }}$ June 2004

18. Jung-Ho Wee, Which type of fuel cell is more competitive for portable application: Direct methanol fuel cells or direct borohydride fuel cells?, $1^{\text {st }}$ September 2006

19. Kundu, A., Jang, J.H., 2009. Applications—portable | portable devices: fuel cells. In: Garche, J. (Ed.), Encyclopedia of Electrochemical Power Sources. Elsevier, Amsterdam, Netherlands. pp. 39-45.

20. Chang, H., Kim, H., Choi, Y.S., Lee, W., 2009. Critical issues in the commercialization of DMFC and role of membranes. In: Zaidi, S.M.J., Matsuura, T. (Eds.), Polymer Membranes for Fuel Cells. Springer, New York, USA, pp. 307-340.

21. Suominen, A., Tuominen, A., Kantola, J., 2011. Analyzing prospects of portable fuel cells with an expert opinion study. Futures 43, 513-524.

22. Stone, C., 2007. Fuel cell technologies powering portable electronic devices. Fuel Cells Bull. 12-15.

23. Cook-Chennault, K.A., Thambi, N., Sastry, A.M., 2008. Powering MEMS portable devices - a review of non-regenerative and regenerative power supply systems with special emphasis on piezoelectric energy harvesting systems. Smart Mater. Struct. 17, 043001 (1)043001 (33).

24. Shimizu, T., Momma, T., Mohamedi, M., Osaka, T., Sarangapani, S., 2004. Design and fabrication of pumpless small direct methanol fuel cells for portable applications. J. Power Sources 137, 277-283.

25. Achmad, F., Kamarudin, S.K., Daud, W.R.W., Majlan, E.H., 2011. Passive direct methanol fuel cells for portable electronic devices. Appl. Energy 88, 1681-1689.

26. Kamarudin, S.K., Achmad, F., Daud, W.R.W., 2009. Overview on the application of direct methanol fuel cell (DMFC) for portable electronic devices. Int. J. Hydrogen Energ. 34, 6902-6916.

27. Rashidi, R., Dincer, I., Naterer, G.F., Berg, P., 2009. Performance evaluation of direct methanol fuel cells for portable applications. J. Power Sources 187, 509-516. 
28. Urbani, F., Squadrito, G., Barbera, O., Giacoppo, G., Passalacqua, E., Zerbinati, O., 2007. Polymer electrolyte fuel cell mini power unit for portable application. J. Power Sources $169,334-337$.

29. Yalcinoz, T., Alam, M.S., 2008. Improved dynamic performance of hybrid PEM fuel cells and ultracapacitors for portable applications. Int. J. Hydrogen Energ. 33, 1932-1940.

30. Scott, D.S., 2004. Until something better comes along! Int. J. Hydrogen Energ. 29, 14391442.

31. Inman, K., Ahmad, Z., Shi, Z., Wang, X., 2011. Design of a proton exchange membrane portable fuel cell system for the 1st international association for hydrogen energy design competition. Int. J. Hydrogen Energ. 36, 13868-13874.

32. Viswanathan, B., Scibioh, M.A., 2006. Handbook of Fuel cells: Principle and Applications. University Press, Hyderabad, India, ISBN 81173715572

33. Kundu, A., Jang, J.H., 2009. Applications-portable | portable devices: fuel cells. In: Garche, J. (Ed.), Encyclopedia of Electrochemical Power Sources. Elsevier, Amsterdam, Netherlands. pp. 39-45.

34. Maynard, H.L., Meyers, J.P., 2002. Miniature fuel cells for portable power: design considerations and challenges. J. Vac. Sci. Technol. B 20, 1287-1297.

35. Dutta, K., Kundu, P.P., Kundu, A., 2014a. Fuel cells-exploratory fuel cells | micro-fuel cells. In: Reedijk, J. (Ed.), Reference Module in Chemistry, Molecular Sciences and Chemical Engineering. Elsevier, Amsterdam, Netherlands. http://dx.doi.org/10.1016/ B978-0-12-409547-2.10975-8.

36. Girish Upreti , David L. Greene , K.G. Duleep, Rapinder Sawhney, Fuel cells for nonautomotive uses: Status and prospects, $16^{\text {th }}$ February 2012

37. Florian Zink, Yixin Lu, Laura Schaefer, A solid oxide fuel cell system for buildings, $7^{\text {th }}$ November 2006

38. M.J. Lavorante, L.G. Messina, J.I. Franco, P. Bonelli, Int. J. Hydrogen Energy 39 (2014) 8631-8634.

39. M.J. Khan, M.T. Iqbal, Appl. Energy 86 (2009) 2429-2442.

40. S.K. Khaitan, M. Raju, Int. J. Hydrogen Energy 37 (2012) 2344-2352

41. Lewis, J. Stationary Fuel Cell. Insight Into Commercialisation. international journal of hydrogen energy 39 (2014) $21896-21901$. 
42. The fuel cell today industry review 2013.

43. Toshiba presentation to the FCH JU stakeholders assembly 13th Nov 2013

44. IEA Insights Series 2013. CHP/DHC country scorecard Japan; 2013

45. ene.field website: www.enefield.eu

46. FCH JU stakeholder general assembly 2013

47. Fuel Cell Energy website: www.fuelcellenergy.com.

48. Bloom Energy website: www.bloomenergy.com

49. Lim, W., Lee, D., Kim, M., Choe, J., Nam, S., Lee, G. D., 2015. Composite structures for Proton Exchange Membrane fuel cells (PEMFC) and Energy Storage Systems (ESSs). Composite structures volume 134 pages 927 - 949.

50. Varma, A., Hanna, D., Diwan, M., 2010. Method to release hydrogen from ammonia borane for portable fuel cells application.

51. Assistant Secretary of Defense for Operational Energy Plans \& Programs, Energy for the Warfighter: Operational Energy Strategy, U.S. Dept. of Defense, 2011.

52. Grew, N.K., Brownlee, B.Z., Shukla, C.K., Chu, D., 2011. Assessment of Alane as hydrogen storage media for portable fuel cell power storage. Power sources 217 (2012) $417-430$.

53. I.M. Robertson, D.D. Graham, J. Graetz, J. Reilly, J.E. Wegrzyn, J. Location of Ti Catalyst in the Reversible AlH3 Adduct of Triethylenediamine Phys. Chem. C 114 (2010) 15207 15211.

54. E.H. Yu, U. Krewer, K. Scott, Principles and Material Aspect of Direct Alkaline Alcohol Fuel cells. Energies 3 (2010) 1499 -1528.

55. J.A. Kumar, P. Kalyani, R. Saravanan, Int. J. Electrochem. J.A. Kumar, P. Kalyani, R. Saravanan, Studies on Pem Fuel Cells Using Various Alcohols for Low Power Applications Int. J. Electrochem. Soc. 3 (2008) 961 - 969.

56. C. Lamy, E.M. Belgsir, J.M. Leger, Electrocalytic Oxidation of Aliphatic alcohols; Application of the Direct Alcohol Fuel Cell. J. Appl. Electrochem. 31 (2001) 799 - 809.

57. A. Serov, C. Kwak, Direct hydrazine fuel cell: A review. Catal. B Environ. 98 (2010) 1 9. 
58. K. Asazawa, T. Sakamoto, S. Yamaguchi, K. Yamada, H. Fujikawa, H. Tanaka, K. Oguro, Study of anode catalysts and fuel concentration on direct hydrazine alkaline anion exchange membrane fuel cell. J. Electrochem. Soc. 156 (2009) B509 - B512.

59. H.W. Li, Y.G. Yan, S. Orimo, A. Zuttel, C.M. Jensen, Recent Progress in Metal Borohydrides for Hydrogen Storage. Energies 4 (2011) 185 - 214.

60. H.W. Li, S. Orimo, Y. Nakamori, K. Miwa, N. Ohba, S. Towata, A. Zuttel, Material designing of metal borohydrides: viewpoints from thermodynamical stability. J. Alloy Comp. 446 (2007) $315-318$.

61. H. Senoh, Z. Siroma, N. Fujiwara, K. Yasuda. A fundamental study on electrochemical hydrogen generation from borohydrides. J. Power Sources 185 (2008) 1 - 5.

62. E. Bostic, N. Sifer, C. Bolton, U. Ritter, T. Dubois. The US Army Foreign Comparative Test Fuel Cell Programme. J. Power Sources 137 (2004) 76 -79.

63. J. Graetz, J.J. Reilly, V.A. Yartys, J.P. Maehlen, B.M. Bulychev, V.E. Antonov, B.P. Tarasov, I.E. Gabis. Aluminum hydride as a hydrogen and energy storage material: past, present and future. J. Alloy Comp. 509 (2011) S517- S528

64. J. Graetz, J.J. Reilly: Kinetically Stabilized Hydrogen Storage Materials. Scr. Mater. (2007) 56, 835-839.

65. J. Graetz, S. Chaudhari, J. Wegrzyn, Y. Celebi, J.R. Johnson, W. Zhou, J.J. Reilly: The Direct and Reversible Synthesis of AlH3: Triethylenediamine from Al and H2. J. Phys. Chem. C (2007) 111, 19148-19152.

66. D. Lacina, J. Reilly, J. Johnson, J. Wegrzyn, J. Graetz: The Reversible Synthesis of Bis(Quinuclidine) Alane. J. Alloys Compd. (2011) 509S, S654-S657.

67. D. Lacina, J. Wegrzyn, J. Reilly, J. Johnson, Y. Celebi, J. Graetz: Regeneration of Aluminum Hydride using Trimethylamine. J. Phys. Chem. C (2011) 115, 3789-3793.

68. D. Lacina, J. Wegrzyn, J. Reilly, Y. Celebi, J. Graetz: Characterization of Dimethylethylaminealane and the Regeneration of Aluminum Hydride. Energy Environ. Sci. (2010) 3, 1099-1105.

69. J. Graetz, J. Wegrzyn. J.J. Reilly: Regeneration of lithium aluminum hydride (LiAlH4). J. Amer. Chem. Soc. (2008) 130, 17790-17794 [PU]. 
70. Lim, W., Lee, D., Kim, M., Choe, J., Nam, S., Lee, G. D., 2015. Composite structures for Proton Exchange Membrane fuel cells (PEMFC) and Energy Storage Systems (ESSs). Composite structures volume 134 pages 927 - 949 .

71. James, B.D., Kalinoski, J., Baum, K., 2011. Manufacturing cost analysis of fuel cell systems. In: Proc DOE Hydrogen and Fuel Cells Annual Merit Review, Washington, DC.

72. Zhang, J., 2008. PEM fuel cell electrocatalysis. http://www.scitopics.com/PEM_fuel_cell_electrocatalysis.html (Accessed: 13/09/2015)

73. Shaw, L., Pratt, J., Klebanoff, L., Johnson, T., Arienti, M., Moreno, M., 2013. Analysis of H2 storage needs for early market "man-portable" fuel cell applications. Int. J. Hydrogen Res. 38, 2810-2823.

74. Cottrell, C.A., Grasman, S.E., Thomas, M., Martin, K.B., Sheffield, J.W., 2011. Strategies for stationary and portable fuel cell markets. Int. J. Hydrogen Energ. 36, 7969-7975.

75. Pollet, B.G., Staffell, I., Shang, J.L., 2012. Current status of hybrid, battery and fuel cell electric vehicles: from electrochemistry to market prospects. Electrochim. Acta 84, 235249.

76. Dutta, K., Kumar, P., Das, S., Kundu, P.P., 2014b. Utilization of conducting polymers in fabricating polymer electrolyte membranes for application in direct methanol fuel cells. Polym. Rev. 54, 1-32.

77. Dutta, K., Das, S., Kumar, P., Kundu, P.P., 2014c. Polymer electrolyte membrane with high selectivity ratio for direct methanol fuel cells: a preliminary study based on blends of partially sulfonated polymers polyaniline and PVdF-co-HFP. Appl. Energy 118, 183-191.

78. Dutta, K., Das, S., Kumar, P., Kundu, P.P., 2014d. Low methanol permeable and highly selective membranes composed of pure and/or partially sulfonated PVdF - co - HFP.Appl. Energy 118, $183-191$.

79. Dutta, K., Das, S., Kundu, P.P., 2015a. Partially sulfonated polyaniline induced high ionexchange capacity and selectivity of Nafion membrane for application in direct methanol fuel cells. J. Membr. Sci. 473, 94-101.

80. Dutta, K., Das, S., Rana, D., Kundu, P.P., 2015b. Enhancements of catalyst distribution and functioning upon utilization of conducting polymers as supporting matrices in DMFCs: a review. Polym. Rev. 55, 1-56. 
81. Das, S., Kumar, P., Dutta, K., Kundu, P.P., 2014. Partial sulfonation of PVdF-co-HFP: a preliminary study and characterization for application in direct methanol fuel cell. Appl. Energy 113, 169-177.

82. Kumar, P., Dutta, K., Das, S., Kundu, P.P., 2014. Membrane prepared by incorporation of crosslinked sulfonated polystyrene in the blend of PVdF-co-HFP/Nafion: a preliminary evaluation for application in DMFC. Appl. Energy 123, 66-74.

83. Zhang, H., Shen, P.K., 2012. Recent development of polymer electrolyte membranes for fuel cells. Chem. Rev. 112, 2780-2832.

84. Moreno, F.J., Guelbenzu, G., Folgado, M.A., Aparicio, F.P., Chaparro, A.M., 2013. A portable system powered with hydrogen and one single air - breathing PEM fuel cell. CIEMAT, Department of Energy, Avda. Complutense, 40, 28040 madrid spain.

85. Wall street journal 19th Feb 2014.

86. Fuel cell energy Q2 report; 2013.

87. Panasonic press release; Jan 2013.

88. Toshiba press release; Jan 2012.

89. FC Expo 2013 Presentation by METI.

90. Micro-CHP Fuel Cell System Targets. DoE hydrogen and fuel cell progress report; Oct 2011.

91. FCH JU. Revised multi-annual implementation plan; 2012.

92. Ceramic fuel cells press release; 2012.

93. Fuel cell today; 2013

94. City of Nagoya; 2013.

95. Reported at the Piero Lunhgi Conference Rome December 2013; also KPMG Global Energy and Natural Resources country site.

96. UK H2 mobility phase 1 results April 2013.

97. Land securities development at Fenchurch Street, London and Crown estates development at Regent street, London.

98. Reported at the SHFCA Edinburgh Conference for Stationary Fuel Cells November 2013.

99. US DoE. Energy efficiency and renewable energy case study. First National Bank of Omaha. 
100. Wang, J, 2015. Barriers of Scaling up Fuel Cells: Cost, Durability and Reliability. Energy $80,509-521$.

101. Pei, P., Huicui, C, 2014. Main factors affecting the lifetime of Proton Exchange Membrane Fuel Cells in Vehicle Application: Review Appl. Energy 125, 60-75. 